\title{
MAKNA SIMBOLIK TOPENG TARIAN HUDOQ PADA UPACARA PANEN MASYARAKAT SUKU DAYAK
}

\author{
Nur Hikmah Yanti \\ Universitas Negeri Yogyakarta \\ E-mail: nurhikmahyanti@gmail.com
}

\begin{abstract}
Abstrak
Penelitian ini bertujuan untuk mengetahui latar belakang terciptanya upacara panen masyarakat Dayak, mengetahui fungsi dari tarian Hudoq pada upacara panen masyarakat suku Dayak, makna simbolik apa saja yang ada di dalam topeng hudoq yang digunakan saat upacara panen masyarakat suku Dayak. Hasil penelusuran dinyatakan bahwa, terjadinya upacara panen masyarakat Dayak dilatar belakangi oleh rasa rindu Heleang Hebeung kepada istri dan anaknya yang telah berpisah, Tari Hudoq berfungsi sebagai tari upacara untuk menghadirkan kekuatan serta pengaruh alam yang merupakan tradisi dan kepercayaan Dayak Ga'ay pada musim panen, terdapat tiga jenis topeng Hudoq yang digunakan, yaitu: Hudoq nyam'ake, yang melambangkan pemuda yang gagah berani yang bertugas sebagai prajurit; Hudoq urung pakau, dikenakan oleh orang yang dituakan di kampung, yaitu pemimpin kelas menengah yang memberikan komando kepada prajurit saat perang; Hudoq ba'kap, yaitu dikenakan oleh pemimpin adat yang sekaligus mengepalai tarian Hudoq.
\end{abstract}

Kata kunci: Makna simbolik, Hudoq, upacara panen

\section{THE SYMBOLIC MEANINGS OF THE HUDOQ DANCE'S MASK IN DAYAK COMMUNITY HARVEST CEREMONY}

\begin{abstract}
This researchwas aimed atinvestigating the background of the creation of Dayak community harvest ceremony, the function of the Hudoq dance at the harvest ceremony, any symbolic meaning in the Hudoq mask used during the ceremony. Results showed that the creation of the ceremony was motivated by Heleang Hebeung's longing to his separated wife and children. The Hudoq dance functioned as a ceremonial dance to present strength and the influence of nature which becomes the tradition and belief of Dayak Ga'ay during the harvest season. There are three types of Hudoq masks used, namely: Hudoq nyam'ake, which symbolizes the brave young man who served as a soldier; Hudoq failed, worn by people in the village, namely middle class leaders who gave command to soldiers during the war; Hudoq ba'kap, which is worn by a traditional leader who also leads the Hudoq dance.
\end{abstract}

Keywords: Symbolic meaning, hudoq, harvest ceremony

\section{PENDAHULUAN}

Upacara adat adalah upacara yang dilakukan secara turun temurun yang berlaku disuatu daerah.dengan demikian, setiap daerah memiliki upacara adat sendiri-sendiri. Upacara adat yang dilakukan di daerah, sebenarnya juga tidak lepas dari unsur sejarah. Upacara merupkan serangkaian tindakan atau perbuatan yang terikat pada aturan tertentu berdasarkan adat istiadat, agama dan kepercayaan. upacara 
pada dasarnya merupakan bentuk perilaku masyarakat yang menunjukan kesadaran terhadap masa lalunya. Upacara adat juga kerap kaitannya dengan tarian, sehingga upacara adat kerap dijumpai dengan tarian khas daerah setempat dengan makna sibol tarian dan fungsinya seperti upacara adat hudoq dari suku dayak yang di dalamnya terdapat tarian yang bermakna simbolik pada upacara adatnya.

Tarian hudoq ini merupakan upaca adat dari suku dayak yang dilaksanakan pada saat masyarakat dayak membuka lahan untuk bercocok tanam. Tradisi suku dayak yang setiap tahunnya bercocok tanam dengan cara berpindah-pindah membuat masyarakat suku dayak belum memahami kondisi terburuk yang kemungkinan terjadi daerah lahan yang baru. Sehingga upacara adat ini bertujuan untuk mengetahui nasib dari hasil cocok tanam di lahan baru tersebut, dengan bantuan para leluhur mereka.

Upacara adat hudoq ini memiliki simbolsimbol yang digunakan masyarakat dalam melaksanakan upacara adat ini, baik dari pakaian, tarian, maupun pemimpin upacaranya sendiri.

\section{PEMBAHASAN}

\section{A. Bentuk Upacara Adat}

Sejak lahir kesenian tidak menunjukan sifat materialistis (ekonomis) karena masyarakat pendukukngnya menganggap seni digunakan sebagai media renungan yang bersifat spiritualistis, dan didalamnya sarat dengan arti simbolik yang memancarkan nilai-nilai seperti estetis, etis, romantis, moralitas, dan religius. Dengan perantara seni tersebut seseorang (seniman) bisa bersatu, segera, berdialog dengan Tuhan/Dewa, dalam suatu upacara ritual. Itulah suatu keganjilan dalam alam gaib. Di situ telah bersatu seorang manusia dengan Tuhannya, yang digambarkan sebagai bersatunya mikrokosmos (jagat kecil) dan makrokosmos (jagad besar), atau wis nyawiji antara makhluk dan qaliknya atau dalam konsep Jawa dinamakan manunggaling kawula lan Gusti. Inilah bagian dari bentuk upacara ritual yang sampai sekarang masih bangyak kita jumpai di kraton Surakarta, kraton Yogyakarya, serta upacara-upacara budaya di pelosokpelosok derah Jawa, Bali, Toraja, Kalimantan, dan sebagainya. Peristiwanya dapat meliputi hari ulangtahun raja, persta panen, besih desa, upacara magis, upacara kesuburan, upacara kematian, upacara ruwatan, dan upacara keagamaan (Sutiyono, 1994: 21).

Di samping itu, seni tradisional sendiri mempunyai nilai sakral (magic). Sebagai contoh dalam seni pertunjukan tradisional kerakyatan yang sederhana, misalnya kuda lumping, terdapat pemain dalam kondisi in trances (kesurupan/ndadi) dan makan kaca. Kondisi ini akan kembali bila dibacakan mantra-mantra dari para ahlinya. Masyarakat ini menurut Peursen (1970:41) merupakan kelompok masyarakat mistis. Bentuk kesenian ini pada jaman dulu merupakan bagian sebuah penampilan, pertunjukan, dari upacara spiritual masyarakat sehabis panen raya.

Upacara adat adalah salah satu tradisi masyarakat tradisional yang masih dianggap memiliki nilai-nilai yang masih cukup relevan bagi kebutuhan masyarakat pendukungnya. Selain sebagai usaha manusia untuk dapat berhubungan dengan arwah para leluhur, juga merupakan perwujudan kemampuan manusia untuk menyesuaikan diri secara aktif terhadap alam atau lingkungannya dalam arti luas.

Hubungan antara alam dan manusia adalah sebuah keharusan yang tidak dapat ditolak, karena hubungan tersebut memiliki nilai-nilai sakral yang sangat tinggi. Hal ini diungkapkan dalam personifikasi mistik kekuatan alam, yakni kepercayaan pada makhluk gaib, kepercayaan pada dewa pencipta, atau dengan mengkonseptualisasikan hubungan antara berbagai kelompok sosial sebagai hubungan antara binatang-binatang, burung-burung, atau kekuatan-kekuatan alam (Keesing, 1992: 131).

Upacara adat erat kaitannya dengan ritualritual keagamaan atau disebut juga dengan ritus. Ritus adalah alat manusia religius untuk melakukan perubahan. Ia juga dikatakan sebagai simbolis agama, atau ritual itu merupakan "agama dan tindakan" (Ghazali, 2011 : 50). Ritual keagamaan yang dilakukan 
oleh masyarakat berdasarkan kepercayaan yang dianut oleh masyarakatnya, kepercayaan seperti inilah yang mendorong manusia untuk melakukan berbagai perbuatan atau tindakan yang bertujuan mencari hubungan dengan dunia gaib penguasa alam melalui ritual-ritual, baik ritual keagamaan (religious ceremonies) maupun ritual ritual adat lainnya yang dirasakan oleh masyarakat sebagai saat-saat genting, yang bisa membawa bahaya gaib, kesengsaraan dan penyakit kepada manusia maupun tanaman (Koentjaraningrat, 1985: 243-246).

Orang Dayak mempunyai pengertian tentang ketuhanan, namun bukan dalam arti agama Yahudi, Kristen, dan Islam. Orang Dayak sungguh beragama, namun agama atau kepercayaan terbatas pada lingkungannya sendiri, berhubungan dengan ikatan esensial terhadap nenek moyangnya. Kepecayaannya tidak bermaksud dan tidak mempunyai sifat untuk menjadi agama universal. Bahkan sejak dulu tidak ada kata atau istilah untuk kata agama dalam bahasa-bahasa Dayak. Pandangan terhadap dunia, hukum, kepercayaan, hubungan dengan masyarakat, dan kebiasaan lain, semuanya itu merupakan tradisi.

Yang paling sentral dalam pemikiran orang Dayak adalah contoh-contoh perbuatan yang diturunkan nenek moyang kepada generasi selanjutnya. Keseluruhan peraturan itu yang menentukan cara berfikir serta tingkah laku orang sebagai anggota masyarakat. Dari keseluruhan warisan adat ini merupakan suatu karunia dari nenek moyang akan membawa kemakmuran, kepastian, damai, dan kesejahteraan baik orang untuk perorangan maupun untuk masyarakat.

Salah satu upacara adat yang dilakukan oleh masyarakat Dayak adalah upacara panen padi yang dilakukan pada bulan-bulan yang telah ditentukan sesuai dengan sistem penanggalan tradisional Dayak berdasar perhitungan pergeseran bulan. Upacara panen yang oleh masyarakat Dayak Ga'ay di Tumbit Dayak disebut Bekudung ini dilaksanakan setiap dua tahun sekali pada bulan Agustus.

Keyakinan dengan sistem upacara keagamaan secara khusus mengandung empat aspek yang menjadi perhatian khusus dari para ahli antropologi ialah: (a) tempat upacara keagamaan dilakukan; (b) saat-saat upacara keagamaan dilakukan; (c) benda-benda dan alat upacara; (d) orang-orang yang melakukan dan memimpin upacara. (Koentjaraningrat, 2009: 296).

Pada pelaksanaan upacara ini melibatkan seluruh partisipasi warga kampung, baik dari segi tenaga dan biaya ditanggung bersama dengan mengundang warga Tumbit Dayak dan warga kampung lainnya. Sebelum upacara dilaksanakan, Kepala Adat mengundang warganya untuk bermusyawarah untuk menghitung dan memilih waktu yang tepat sesuai dengan adat atau bulan padi. Persiapan konsumsi massal, persiapan ritual, dan alat daun-daunan untuk busana adat Tari Hudoq.

Upacara pertama dilakukan dilamin atau rumah adat untuk membersihkan benda-benda pusaka, lalu ritual dilakukan di lapangan terbuka oleh seorang Kepala Kudung yakni sesepuh adat yang telah mendapat kepercayaan memimpin ritual. Kegiatan selanjutnya mempersiapkan sesajen berupa: patung lakilaki dan perempuan, ayam dan satu pucuk padi yang nantinya di taruh di atas perahu kecil untuk dihanyutkan di sungai.

Sebelum memulai tari-tarian, ada ritual spesifik yang harus dilakukan terlebih dahulu. Ritual ini disebut dengan Napoq. Ritual ini sangat sakral dan hanya boleh dilakukan oleh orang pilihan yang disebut Dayung (semacam ahli supranatural). Dayung sendiri harus memiliki kemampuan istimewa, yaitu dapat berkomunikasi dengan roh atau dewa.

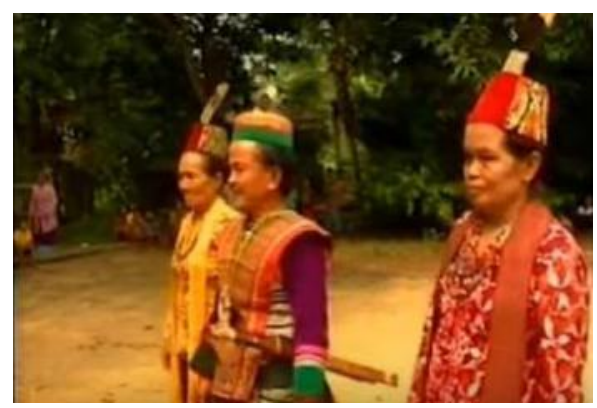

Dayung dengan dua orang asistennya 
Dayung ini akan didampingi oleh dua orang asisten. Mereka kemudian berkeliling kampung sambil membunyikan gong kecil. Gong kecil ini fungsinya sebagai media komunikasi, dan bunyi-bunyian gong kecil itu diyakini sebagai sapaan kepada dewa/roh penjaga desa dan memberitahu bahwa Napoq sedang dilakukan buat memulai tarian Hudoq.

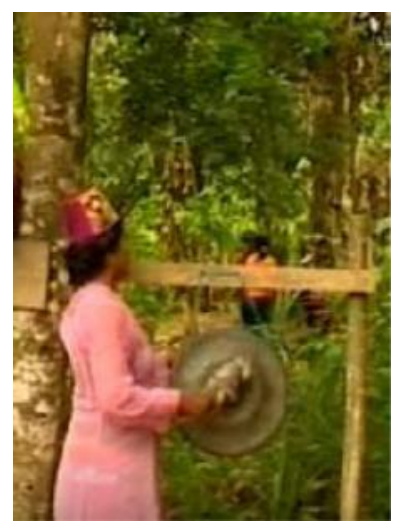

Ilustrasi pembunyian gong

Selanjutnya, Dayung akan memanggil Sang Penguasa Alam dan memohon agar penyelenggaraan tari Hudoq dapat berjalan lancar. Setelah memanggil para dewa untuk merasuki penari Hudoq, selanjutnya Dayung bersama asistennya akan melanjutkan ritual selanjutnya, yaitu menjamu para dewa dengan makanan yang sudah disiapkan, ini semacam "jamuan" makan Gan.

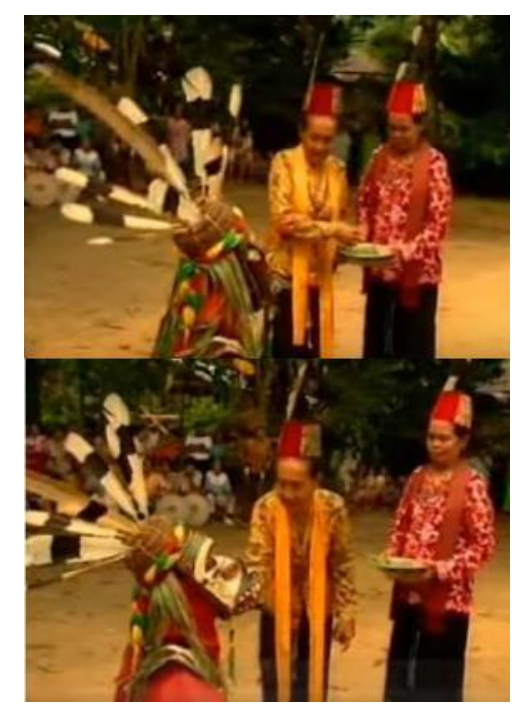

Dayung sedang "menjamu” makan
Dayung akan berdialog dengan para dewa menggunakan bahasa Dayak nan halus dimana hanya dapat dimengerti dan diterjemahkan oleh sang Dayung sendiri. Pada obrolan ini, Dayung akan memohon agar huma pertanian mereka dijaga dan dilindungi. Dan Dayung dapat mengetahui apakah hasil panen nantinya baik atau malah sebaliknya.Bila prosesi ini sudah selesai, maka tari Hudoq pun bisa dilaksanakan.

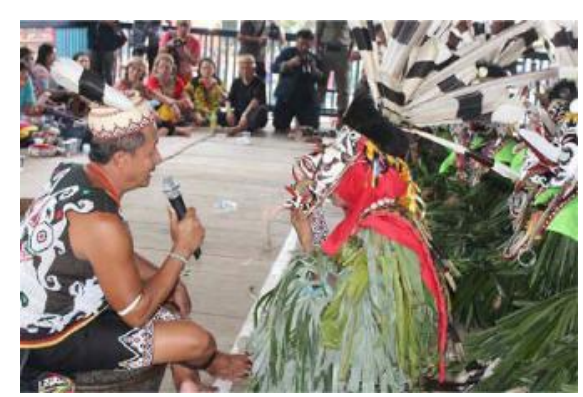

\section{Komunikasi dengan Dayung}

Para penari yang sudah kerasukan dewa akan berbaris diurutkan berdasarkan strata atau kelas sosial dewa. Dewa tertinggi biasanya akan berdiri paling depan. Para penari ini kemudian melakukan ritual yang disebut menarik nyawa padi dengan mengucapkan mantra.

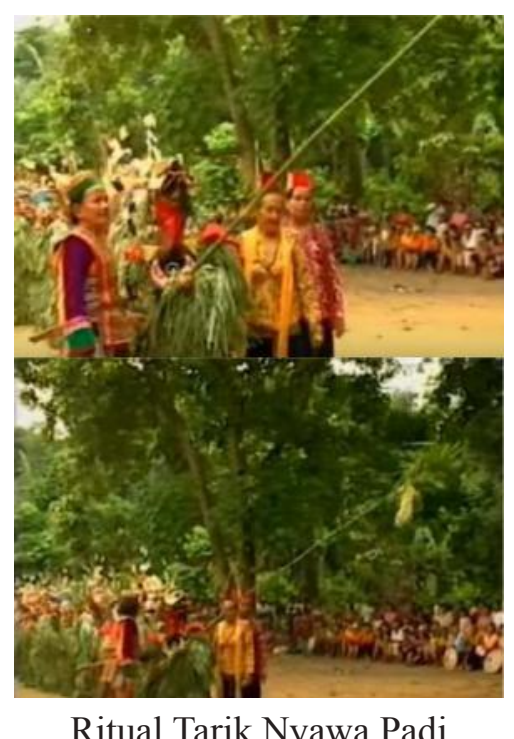

Ritual Tarik Nyawa Padi 
Kemudian akan dilanjutkan dengan menari. Gerakan tari Hudoq memiliki makna filosofis yang tinggi.

Tarian Hudoq ini merupakan acara rutin yang dilaksanakan setiap tahun. Gelaran ini diisi dengan berbagai tarian khas suku dayak seperti tari Hudoq, salah satu tari khas suku Dayak dan juga menjadi mascot Kabupaten Mahakam Ulu.

Tari Hudoq biasanya ditampilkan sekitar bulan September sampai Oktober atau waktu selesai menanam padi. Suku Dayak percaya, Hudoq mampu mengusir hama maupun keburukan hingga nanti huma pertanian tetap baik dengan dan hasil panen dapat berlimpah.

\section{Tarian}

Batasan seni tari yang pernah dikemukakan oleh para pakar, pada hakikatnya mengatakan bahwa tari adalah ekspresi perasaan manusia yang diungkapkan lewat gerak ritmis dan indah yang telah mengalami stilisasi maupun distorsi (Soedarsono dalam Hadi, 2007:29).

"Keindahan" dalam seni tari berkaitan dengan kandungan isi, makna atau pesan tertentu. Hal - hal yang terperinci seperti struktur, bentuk, kerumitan, kehalusan, dan sebagainya, mungkin tidak indah, namun sebagai keseluruhan wujud, dengan segala isi, makna dan pesannya, seringkali karya tersebut dikatakan indah (Hadi, 2007:13-15).

Kehadiran tari tidak bersifat independen, dilihat secara tekstual tari dapat dipahami dari bentuk dan teknik yang berkaitan dengan komposisinya (analisis bentuk atau penataan koreografi) atau teknik penarinya (analisa cara melakukan atau keterampilan). Sementara dilihat secara kontekstual yang berhubungan dengan ilmu sosiologi atau antropologi, tari adalah bagian yang tidak dapat dipisahkan dari dinamika sosio - kultural masyarakat (Hadi, 2007:13).

Tari lahir dari aktivitas masyarakat yang sederhana, kemudian berkembang dan seterusnya melekat sehingga menjadikannya bagian yang tidak dapat dipisahkan dalam masyarakat. Dilihat dari sisi konteks tari yang berhubungan dengan ilmu sosiologi,
Sumandiyo Hadi (2007:11) menyatakan tinjauan atau pandangan dari ilmu - ilmu sosial termasuk dalam hal ini sosiologi, akan mencari tau tentang hakikat dan sebab-musabab berbagai pola pikiran dan tindakan manusia yang bersifat generalisasi empirik. Sosiologi lebih memperhatikan gejala kelompok atau individu yang teratur, mencari hukum atau aturan yang melekat dengan mempelajari pola struktur tindakan atau kelakuan manusia dengan interaksi antar - manusia.

Tari Hudoq biasanya digelar di lapangan atau sawah yang akan ditanami. Gerakan tari ini memiliki ritme yang cukup tinggi dan beberapa gerakan dengan filosofi tersendiri. Salah satunya ialah gerakan mengibasngibaskan tangan seperti gerakan sayap burung sedang terbang. Para penari juga melakukan gerakan Nyidok atau Nyebit, yaitu gerakan maju sambil menghentakkan kaki. Gerakan ini bermakna untuk mengusir hama penyakit agar tidak menyerang tanaman padi. Selain itu, para penari akan melakukan gerakan memutar ke kiri dan ke kanan. Berputar ke kiri bermakna membuang kesialan, sementara berputar ke kanan diyakini sebagai gerakan meraih kebaikan.

\section{Busana}

Topeng diartikan sebagai penutup muka yang dibuat dari kayu (kertas dan sebagainya) yang berupa muka orang (binatang dan sebagainya) Istilah topeng dapat mempunyai banyak pengertian : Oleh Karena itu perlu diberi penjelasan untuk memperoleh kesatuan pendapat dan seragam pemikiran sesuai dengan tujuan dari penulisan ini

Istilah topeng dalam percakapan sehari-hari sering kita dengar seperti, manusia bertopeng. Dalam artian ini kata topeng semata-mata berarti benda penutup "muka" agar identitas individu itu tidak dikenal, atau agar terjadi suatu perubahan dalam bentuk muka orang dari wujudnya semula.

Pengertian topeng sebagai penutup muka dengan mudah dapat kita perhatiakna dari gejala bahasa"formatif" (pembentukan kata), kata topeng berasal dari "tup" yang 
berarti tutup, kata tup ditambah saja dengan "eng" yang kemudian mengalami beberapa perubahan sehingga menjadi topeng $>$ Arti lain dari topeng adalah "tapel":"... for topeng simply means something presed against the face,I, e, a mask") Topeng secara mudah adalah benda yang ditekankan pada muka yaitu tapel. Tapel atau topeng dapat dapat dibuat dari kayu, kertas tebal papier mache, dari kulit, kain dan bahan-bahan lainnya serta dapat digunakan untuk menutup muka atau sebagian dari muka.

Topeng Hudoq diwujudkan dengan bentuk mata yang besar, mulutnya yang dibuka lebar, dan dengan gigi-giginya yang mencolok. Warna yang umumnya dipakai, untuk wilayah muka yaitu warna putih kemudian bagian lingkaran mata dan mulut warna hitam dan merah.

Ada topeng Hudoq yang hanya memakai dua warna saja yaitu putih dan hitam. Ada juga topeng yang berwarna asli kayu dengan garis-garis mata, hidung dan mulut berwarna putih. Topeng Hudoq yang lain ada yang diberi rambut dari ijuk hitam kaku yang menghias kepala bagian depan, kumis, dan jenggot, serta ada juga yang menghiasi bagian hidung; keluar dari lubang hidung.

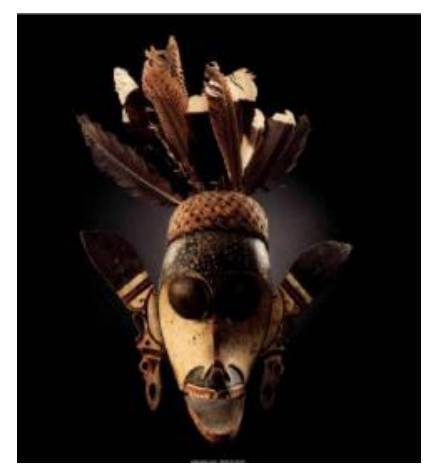

Topeng Hudoq Dayak

Di kepala topeng Hudoq ini juga ada yang diberi hiasan bulu burung enggan putih dan hitam ditusuk kan di atas kepala yang beranyam rotan. Topeng-topeng itupun punyai telinga yang panjang dan tegak vertikal. Ada yang diberi anting-anting panjang dan ada juga yang diberi bandulan anting dari perunggu.

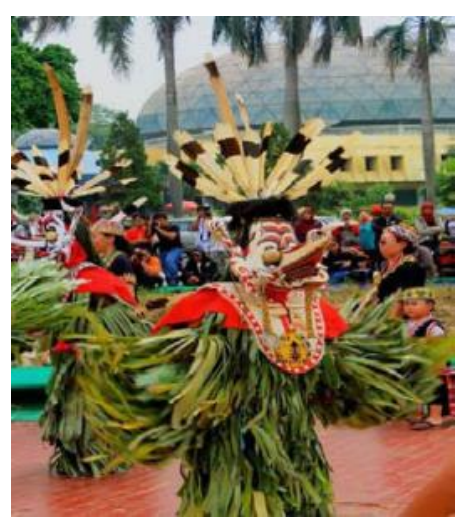

Busana penari hudoq

Daun pisang pada Hudoq tidak lepas dari keyakinan suku Dayak, dimana daun itu melambangkan kesejahteraan dan kesejukan. Lalu untuk topengnya sendiri yang mirip burung adalah perwujudan paras dari dewa Hunyang Tenangan. Makna lainnya adalah perwujudan burung elang yang melindungi musim panen. Di topeng ini biasanya ada rona merah atau kuning yaitu warna-warna kesukaan para dewa. Bentuk topeng ini beragam, namun ciri khasnya mudah dikenali.

\section{B. Karakteristik Suku Dayak}

Bicara tentang suku bangsa Dayak, potret masa lalu ketika bangsa ini berada dalam lingkungan kekuasaan rezim orde baru, kontruksi pikiran kita sudah barang tentu akan diajak daan dituntun pada sebuah gambaran stereotif yang menyatakan bahwa Dayak itu memiliki pola hidup yang misterius, sakti, tradisional, nomaden, ketinggalan zaman, kanibal, dan sebagainya. namun, jika mau melihat kesejarah masa silam, sesungguhnya istilah Dayak itu baru mulai dikenal nunia setelah adanya penemuan Dr. Agust Kanderlan, seorang sosiolog Belanda tahun 1803. Dalam penemuannya tersebut, dia menjelaskan bahwa penduduk yang ia temui di pedalaman Borneo (Kalimantan) mengaku diri sebagai "Orang Daya", koloni manusia yang tinggal di kawasan perhuluan sungai dan memeluk kepercayaan non muslim.

Kata Dayak berasal dari kata daya dari bahasa Kenyah, yang berarti hulu sungai atau 
pedalaman. King, lebih jauh menduga-duga bahwa Dayak mungkin juga berasal dari kata aja, sebuah kata dari bahasa Melayu yang berarti asli atau pribumi. Dia juga yakin bahwa kata itu mungkin berasal dari sebuah istilah dari bahasa Jawa Tengah yang berarti perilaku yang tak sesuai atau yang tak pada tempatnya.

Selanjutnya, tulisan-tulisan Dr. Agust memancing rasa ingin tahu banyak ahli dunia, termasuk para peneliti Dayak sendiri mengenai tradisi lama tentang cara hidup, kearifan, kepercayaan, kesatuan dengan alam lingkungan, sampai pada cerita misterius dan menakutkan seperti mengayau.

Umum dikatakan bahwa orang dayak berasal dari Yunan, Cina Selatan, bagian hulu sungai Mekong, layaknya cerita asal usul beberapa suku di seantero nusantara ini seperti Toraja, Nias dan sebagian Melayu. Namun, teori ini masih belum bisa dibuktikan kesahihannya. catatan masa lalu dari hasil penelitian memang mengarah kesana dimana ada kemungkinan bahwa perantau Cina daratan pernah singgah bermukim dan berkembang biak di bumi Borneo ini dan bermutasi menjadi embrio suku bangsa Dayak.

Catatan lain menyebutkan bahwa, jauh sebelum bangsa Austronesia (sebuah bangsa hasil perkawinan silang antar ras mingol dengan ras asli Kalimantan) datang di kepulauan Kalimantan, di kepulauan ini telah hidup dua bangsa besar, bangsa Weddoide dan bangsa Negrito (Wijowarsito, 1957). hal ini menurut Wijowarsito dapat ditelusuri pada garis sejarah dan budaya didua kota yakni di Bengkayang dan Singkawang.

Pada konteks Kabupaten Bengkayang dan Kota Singkawang, dalam batas tertentu, orang Dayak yang tersebar di wilayah ini merupakan klan besar dari apa yang dikenal sebagai Klemantan atau Land Dayak. ada sekitar empat rumpun Dayak diwilayah ini, yakni; rumpun Dayak Kanayatn, Silako, Bidayuh, dan Punan dengan beragam bahasa dan variannya. Seperti di Singkawang, kita akan dengan mudah menemui orang-orang Dayak yang berdialek Bajere, Badameo, atau Damea, Bakati', Banyadu', Bajayan, Baiyam, dan sebagainya(Nistain \& Frans; 1-3).

\section{Masyarakat Ladang}

Masyarakat Kalimantan Timur ini adalah masyarakat ladang. Sifat masyarakat ladang adalah masyarakat pengumpul makanan (pemburu dan peramu) dan masyarakat sawah. Dengan demikian, masyarakat ladang Kalimantan Timur ini bersifat dependen dan independen, konsumtif dan produktif. Prinsip kekeluargaannya erat (domestik), hubungan darah lebih penting dari hubungan lokalitas, serta pentingnya arti batas dan perantara.

Semua sifat masyarakat ladang ini dilandasi atas konsep dualisme keberadaan, yang terdiri atas dua kutub yang berbeda dan saling bertentangan. Kedua kutub tersebut dapat saling bertentangan, namun dapat pula saling melengkapi dan saling ketergantungan satu dengan yang lainnya dalam kehidupan. Perbedaan ini terlihat ketika adanya pemisah antara laki-laki dan perempuan, dunia atas dan dunia bawah yang kemudian melahirkan dunia tengah, seperti ayah dan ibu melahirkan anak.

Persatuan antara dunia atas dan dunia bawah akan menghasilkan suatu kehidupan baru. Karena sifat masyarakat ini adalah segala sesuatu yang bertentangan harus diharmonikan, maka harus ada dunia tengah yang bersifat netral. Masyarakat primitif mengharapkan adanya dunia transendental. Oleh karena itu, terjadilah konsep tiga kesatuan atau tripartit keberadaan yang sempurna, yang merupakan hasil penyatuan dua kutub yang bertentangan yang kemudian saling melengkapi (komplementer).

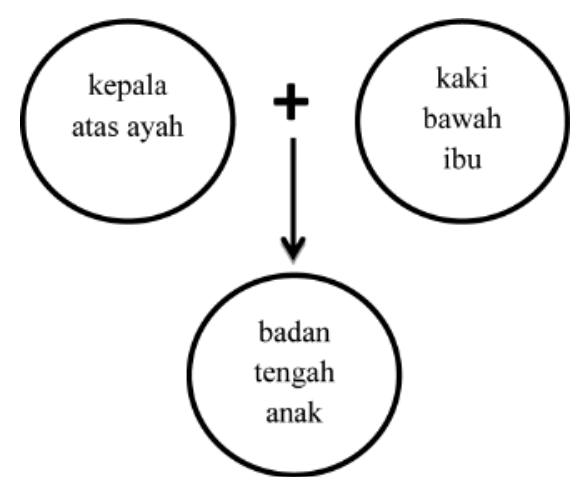

Gambar 1. Konsep Tiga Kesatuan atau Tripartit 
Dasar tinjauan di atas menjadi acuan dalam menganalisis tari dan topeng Hudoq, Kalimantan Timur.

\section{Perkembangan Sejarah}

F. Jiu Luwai (2002:5) menceritakan bahwa himpunan tulisan legenda tari ritual rakyat Ga'ay Long Glaat ini bermula dari perkawinan Heleang Hebeung dari alam manusia di permukaan bumi dengan Selau Sen Yeang yang merupakan seorang Puteri dari kerajaan di dasar pusaran sungai. Dari perkawinan mereka lalu lahirlah anak yang diberi nama Buaq Selo.

Pada saat Heleang Hebeung tinggal di dasar sungai, ia pernah menyaksikan persembahan hiburan berupa tari dari warga makhluk dasar sungai yang datang berkumpul. Setelah berkumpul Selau Sen Yeang meminta kepada warga untuk menari semeriah meriahnya. Maka muncul bunyi-bunyian dan gerak tari dengan karakter masing-masing. Semakin lama semakin nampaklah karakter asli makhluk dasar sungai di dalam tarian tadi. Perlahan lahan tidak terasa Heleang Hebeung yang menggendong anaknya berada di tengah - tengah kerumunan penari. Dari rasa kagum, berangsur menjadi ngeri. Setelah banyaknya para penari dengan karakter aslinya yang menakutkan.

Apa yang dimaksud Selau Sen Yeang untuk menghibur Heleang Hebeung justru membuat trauma bagi dirinya dan semakin tidak betah apalagi kehidupannya pada saat itu ingin kembali kepada sanak keluarga di alam bumi hidup seperti semula. Maka dengan berat hati istrinya mengabulkan kehendaknya disetujui pula oleh ayah Selau Sen Yeang yaitu Pok Sen Yeang. Dengan nada penuh lirih Selau Sen Yeang menyatakan "Dengan rela saya melepas kepergianmu. Kita memang hidup di alam yang berbeda, namun kasih sayangku tidak mengenal dan terhalang oleh alam yang berbeda". Pesan dari Selau Sen Yeang "Bila engkau ingin kembali berhubungan dengan kami, panggil dan buatlah upacara adat kami akan membantu dalam berbagai keperluan. Hubungan ini tidak akan terputus sampai kapanpun, Buaq Selo dan keturunannya kelak akan memelihara sampai kapanpun tidak akan berakhir."

Heleang Hebeung berusaha mengingat kejadian tontonan atau hiburan yang diselenggarakan oleh istrinya walau kelihatannya menyeramkan. Kemudian menceritakan kepada warga apa yang dialaminya. Untuk mengenang istri dan anaknya serta alam gaib, rakyat Leham Kejin berusaha dengan dipandu Heleang Hebeung membuat topeng-topeng yang mirip dengan ekspresi dan karakter yang dilihatnya. Sejak saat itu pula Heleang Hebeung menjadi Pencetus Tari Hudoq. Tari Hudoq yang berarti tari topeng dan tradisi ini telah berlangsung turun-temurun menjadi bagian dari budaya Kampung Leham Kejin, dan yang sampai saat ini sub Suku Dayak Kayan ini berpindah-pindah tempat, terakhirnya mereka dikenal sebagai sub suku Long Gelaat.

Dari pertemuan dan kawinnya Heleang Hebeung dengan Selau Sen Yeang telah membentuk hubungan makhluk gaib di dunia air dengan manusia. Yang ditandai dengan hubungan darah (oleh Heleang Hebeung) menjadi Hubungan Ritual Kepercayaan, karena adanya kepercayaan bahwa Selau Sen Yeang dan Buaq Selo dapat saling membantu, dalam bentuk pengaruh tidak nyata, dan pengaruh nyata kepada manusia keturunan Heleang Hebeung. Antara lain dalam bentuk pengobatan, pengusiran gangguan jahat serta pemulihan.

Sejak saat itu tari Hudoq menjadi sarana untuk menghadirkan kekuatan, pengaruh alam tradisi dan kepercayaan Dayak. Topeng dalam berbagai corak dan karakter yang menggambarkan kehadiran Tokoh yang berpengaruh dalam berbagai aspek kepercayaan tradisi Dayak. Sebagai contoh nyata aspek kehidupan yaitu pada musim perladangan dan biasanya musim menanam padiatau pada musim panen, digelar pelaksanaan upacara tari Hudoq dimana prinsipnya pelaksanaan upacara Hudoq adalah meminta kekuatan, perlindungan, dan keberhasilan pada usaha perladangan, usaha lainnya, kebersihan kampung dan kedamaian seluruh warga. 
Pada penyajian tari Hudoq rombongan Hudoq bermunculan menuju Lapangan Lamin Adat, sambil menari ria disambut oleh tarian bersama dari para wanita kampung. Kemudian tibalah saat yang telah ditentukan untuk melakukan Acara Ritual Hudoq, yang dinamai Metaang Hudoq. Lalu seorang tokoh Kepala Adat (Sehun Taang) yang diberi peran bertanya kepada rombongan Hudoq, Kepala Hudoq yaitu Hudoq Tonggaep.

\section{Fungsi Tarian Hudoq}

Secara umum terdapat tiga jenis tari pada sebuah pertunjukan, yaitu (1) tari sebagai sarana upacara keagamaan dan upacara adat tradisi, (2) tari bergembira atau tari pergaulan, (3) tari tontonan (Soedarsono, 1999:167-168).

Tari Hudoq berfungsi sebagai tari upacara untuk menghadirkan kekuatan serta pengaruh alam yang merupakan tradisi dan kepercayaan Dayak Ga'ay pada musim panen. Topeng dalam berbagai corak dan karakter yang menggambarkan kehadiran tokoh dewa yang berasal dari sungai, gunung, maupun hutan belantara yang berpengaruh dalam berbagai aspek kepercayaan tradisi mereka. Pertunjukan tari Hudoq pada upacara panen padi penikmatnya adalah para penguasa dunia atas (Sang Pencipta dan roh-roh ghaib) serta dunia bawah (warga dasar sungai).

Dalam upacara Bekudung, tari Hudoq menjadi bagian dari rangkaian upacara yang mana tari ini tergolong ke dalam tari rakyat sebagai aktivitas komunal masyarakat pendukungnya. Hal tersebut terlihat dari partisipasi seluruh masyarakat mulai dari persiapan hingga pelaksanaan upacara. Menurut Soedarsono (1972:20) tari rakyat merupakan tari sakral yang mengandung kekuatan magi, gerak-gerak tarinya sangat sederhana sebab yang dipentingkan adalah keyakinan yang terletak di belakang tarian tersebut.

Tari Hudoq dalam upacara Bekudung mengekspresikan bentuk kesatuan masyarakat Dayak Ga'ay, dalam hal ini masyarakat kampung Tumbit Dayak mengadakan tari Hudoq sebagai sarana untuk menghilangkan kekhawatiran akan terjadinya berbagai hal seperti kegagalan panen. Hudoq berfungsi sebagai media penghubung antara roh-roh gaib dengan manusia yang bermanfaat sebagai sarana komunikasi, ungkapan rasa syukur dan pengharapan, pengikat rasa solidaritas, dan hiburan. Untuk itu, kajian tentang fungsi tari Hudoq diungkap secara rinci sebagai berikut:

a. Sebagai sarana komunikasi kepada roh-roh gaib

Fungsi tari Hudoq sangat berkaitan dengan komunikasiyang berhubungan dengan alam gaib yaitu untuk memanggil roh-roh baik dan mengusir roh-roh jahat lewat penari Hudoq yang menggunakan topeng-topeng yang menggambarkan ekspresi tokohtokoh yang berpengaruh dalam kehidupan masyarakat Dayak.Tokoh topeng Tong Gaep berperan sebagai pemimpin dan penghubung pihak Hudoq dengan manusia yang diwakilkan oleh kepala adat.

b. Sebagai sarana pengungkap rasa syukur Tari Hudoq erat kaitannya dengan upacara panen. Rasa syukur atas perlindungan pada tanaman saat mulai menanam hingga menuai hasil panen yang melimpah tahun ini serta dijauhkan dari segala macam hama perusak tanaman. Rasa syukur itu diwujudkan dengan mengadakan pesta yang diadakan selama beberapa hari dengan mengundang tetangga dan warga kampung lain untuk bersama sama menikmati berkah hasil panen tahun ini. Selain itu rasa syukur juga berkaitan dengan kebersihan kampung dan kedamaian seluruh warga.

c. Sebagai pengikat rasa solidaritas dan kebersamaan masyarakat

Keakraban dan kebersamaan warga di Tumbit Dayak masih sangat kental dan dapat terlihat dari segala macam kegiatan. Dalam kehidupan bertetangga, berladang, membersihkan kampung, maupun pada upacara adat. Pada upacara panen seluruh warga turut membantu dalam mengerjakan persiapan, mulai dari membersihkan kampung, pembuatan ibus (umbul-umbul khas Dayak), menghias rumah adat, membuat lemang serta membuat baju rumbai dedaunan untuk penari Hudoq. 
Seluruh kegiatan tersebut dipimpin oleh kepala kampung yang terus memberikan arahan dan motivasi kepada masyarakat Ga'ay demi kesejahteraan warga dan kemajuan kampung.

d. Sebagai sarana meminta kekuatan, perlindungan, dan keberhasilan pada usaha perladangan

Fungsi utama tari Hudoq yang memang hanya ditampilkan pada masa menanam dan memanen padi adalah untuk meminta kekuatan pada roh-roh pelindung agar menjaga dan membantu manusia untuk keberhasilan pada usaha perladangan. Masyarakat Dayak Ga'ay meyakini bahwa kehidupan mereka saat ini tidak terlepas dari kehidupan nenek moyang mereka yang selalu membantu dalam setiap segi kehidupan.

e. Sebagai sarana hiburan

Berdasarkan sejarah awal terciptanya tari yang dilaksanakan oleh warga penghuni dasar sungai dengan beragam karakter aslinya memiliki tujuan untuk menghibur Heleang Hebeung. Pada perkembangannya tari Hudoq selain menjadi kebutuhan spiritual untuk mendekatkan diri pada roh nenek moyang dalam upacara panen, tetapi berfungsi sebagai hiburan yang dapat dinikmati. Seluruh warga menanti kehadiran para penari Hudoq walaupun penampilan mereka terlihat menakutkan dengan topeng yang menyeramkan dan busana yang terbuat dari daun pisang.

Konsep tripartit diterapkan melalui penyatuan antara masyarakat dan pemimpin yang menghasilkan sebuah adat. Adat istiadat ini dikembangkan oleh masyarakat Dayak, dan salah satunya berupa tarian mistis. Kalangan orang Dayak Bahau, Kalimantan Timur memercayai adanya kekuatan mistis yang melingkupinya, yang kepercayaan tersebut dimanifestasikan lewat tari-tarian. Tarian yang dimaksudkan adalah "Tarian Hudoq" yang merupakan ritual terbesar dan terutama dalam masyarakat Dayak Bahau. Tarian ini, dalam pementasannya menggunakan topeng sebagai alat untuk menghadirkan suasana mistis. Tujuan pelaksanaan upacara dan tarian Hudoq ini adalah untuk menciptakan keselarasan dengan lingkungan alam, terutama sekali agar memperoleh jaminan keberhasilan panen di ladang dengan dibantu oleh dewa. Dengan demikian, tarian ini di samping sebagai tarian mistis juga sebagai tarian animisme (pemujaan pada dewa-dewa). Eksistensi Hudoq tidak bisa dipisahkan dari tradisi berladang. Jika orang Bahau tidak berladang lagi, Hudoq pun akan hilang. Jika pun masih ada, ia tidak mempunyai spirit lagi, tinggallah sebuah seni yang tanpa makna. Kekhawatiran hilangnya hudoq makin hari makin dirasakan generasi tua Dayak Bahau, karena semakin kecilnya lahan untuk berladang akibat masuknya perusahaan hutan yang menguasai, serta orang luar yang masuk untuk mengeksploitasi kayu.

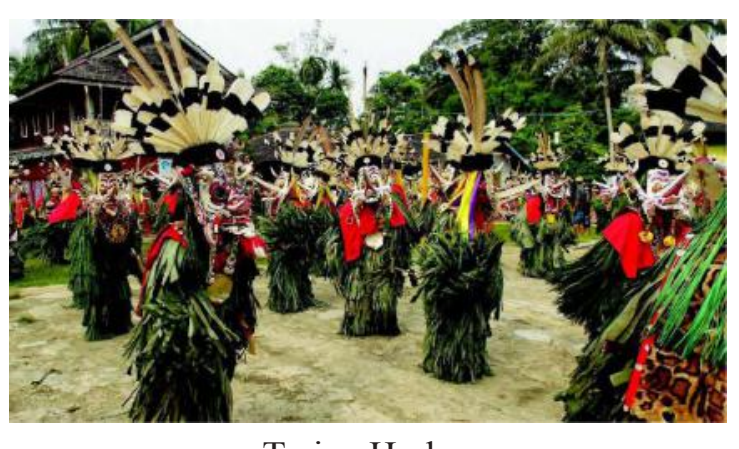

Tarian Hudoq

Tarian Hudoq seperti digambarkan secara ringkas tersebut, hanyalah merupakan salah satu contoh kecil masih dipertahankan dan dilestarikannya tarian tersebut yang mengandung makna tersendiri yang sangat berkaitan dengan kosmologi orang Dayak Bahau. Adapun kehadiran lain tarian Hudoq dalam kehidupan sosial-budaya orang Dayak Bahau adalah dalam acara resmi atau peringatan hari besar, pesta adat dan bahkan dalam pentaspentas seni lainnya, baik dalam skala lokal, nasional, maupun skala internasional.

Hudoq orang Dayak Bahau di aliran sungai Mahakam, dilaksanakan ketika musim menanam padi di ladang, sekitar bulan OktoberNovember. Ritual Hudoq dimaksudkan untuk mengantar jiwa padi dari rumah ke 
ladang. Upacara adat setahun sekali ini harus dilaksanakan dengan semeriah mungkin agar roh padi senang tinggal di ladang.

\section{Makna Simbolik}

Dunia ini menyimpan banyak rahasia yang menunggu untuk diungkapkan, banyak hal yang tidak terbaca karena selalu ada sesuatu yang tidak bisa terungkap secara langsung. Maka dari itu simbol merupakan cara paling tepat untuk membahasakan sesuatu yang tidak bisa diungkapkan dengan mudah. Simbol adalah objek, kejadian, bunyi bicara, atau bentuk-bentuk tulis yang diberi makna oleh manusia.Hanya manusia yang dapat melakukan simbolisasi terhadap sesuatu, karena manusia merupakan makhluk yang mampu menggunakan, mengembangkan, dan menciptakan lambang-lambang atau simbolsimbol untuk berkomunikasi dengan sesamanya (Sindung, 2010:10).

Simbol merupakan alat yang kuat untuk memperluas pengetahuan, merangsang daya imajinasi, dan memperdalam pemahaman. Sebuah simbol dapat dipandang sebagai sebuah objek yang menggambarkan atau menandakan sesuatu yang lebih besar dan tinggi berkaitan dengan sebuah makna, realitas, suatu cita-cita, nilai, presentasi, kepercayaan, masyarakat, konsep, lembaga, dan suatu keadaan(Dillistone, 2002:20).

Kata Hudoq dalam bahasa Dayak Bahau berarti topeng. Hudoq masyarakat Dayak Bahau di aliran sungai Mahakam (Mekam dalam bahasa Dayak Bahau) sama di semua kampung. Tarian Hudoq, penarinya menggunakan topeng yang disebut Hudoq.

Pada masyarakat Dayak Bahau di sungai Pariq, Hudoq dilaksanakan menjelang panen padi di ladang selama 7 atau 10 hari, setiap hari berbeda Hudoq-nya. Urutannya sebagai berikut: Hudoq Suh Doh, Hudoq Lake, Hudoq Tajung Long Belan, Hudoq Tajung Lavung Kirap, Hudoq Suh Doh, Hudoq Kuhaw Habung Ajat Inaang Pa' Pa'an, Hudoq Hakaai, Hudoq Habung Ajat, Hudoq Kalang, dan Hudoq Kuhaw Inaang Pa' Paan.
Puncak Hudoq pada hari terakhir. Pada hari terakhir, semua Hudoq yang pernah tampil, beraksi lagi. Nama-nama Hudoq tersebut membedakan ritual yang dilakukan serta topeng dan aksesori yang dipakai.Pada Hudoq Suh Doh misalnya, sebelum ritual Hudoq dilangsungkan, pewaris Hudoq memanen padi di ladang sekitar $1 \mathrm{~kg}$ dan disimpan dalam ruas bambu. Padi inilah yang ditarikan dan dibuat ritualnya, kemudian pada akhir ritual padi tersebut dibagikan ke semua orang yang hadir. Padi inilah yang kemudian dicampur dengan benih untuk ditanam di ladang tahun berikutnya. Meski agak berbeda masing-masing Hudoq, umumnya bahan utama ritual Hudoq adalah topeng dari kayu, daun pisang dan akar untuk pengikatnya. Topeng untuk menutupi muka dan daun pisang yang dibelah-belah sehingga membentuk rumbai-rumbai diikatkan hingga menutupi kaki, paha, pinggang, tang han dan bahu. Setiap kali berhudoq, daun pisang yang dipakai harus baru. Daun pisang bekas Hudoq tidak boleh dibakar, tetapi ditumpuk dan dibiarkan busuk jadi pupuk.

Pemain Hudoq umumnya harus orang yang bermukim di kampong, tempat Hudoq dilaksanakan. Satu-satunya Hudoq yang bisa dimainkan oleh tamu yang datang atau Hudoq dari kampung lain adalah Hudoq Hakaai. Ketika Hudoq sedang beraksi, ada juga duplikat hama padi di ladang, seperti kera, tikus, babi, rusa, dan burung pipit yang tampil. Hudoq hama ini juga berfungsi sebagai penghibur. Selain Hudoq hama, pada saat bersamaan ada Hudoq perempuan. Hudoq perempuan ini ada yang bertopeng dan ada yang tidak, juga ada yang badannya dibungkus dan ada yang tidak dibungkus dengan rumbai-rumbai daun pisang. Muka dan badan diukir dengan arang pewarna lainnya dan membawa perlengkapan hidup sehari-hari seperti bakul, nyiru, pengambin. Hudoq perempuan ini melakukan atraksi sebagai simbol tradisi dan adat masyarakat Bahau.Misalnya bagaimana orang Bahau berpacaran dan memelihara bayi, bagaimana orang menangkap ikan dan binatang buruan.

Yang menarik pada Hudoq dari desa Telivaq yaitu pemegang adat tertinggi Hudoq 
adalah perempuan.Karena menurut Song Devung, 80 tahun, pemegang adat Hudoq, yang pertama kali menemukan adat Hudoq dan menjadi raja Hudoq adalah perempuan. Sehingga sampai kini yang memimpin ritual Hudoq adalah perempuan. Ini sekaligus cermin dari prinsip dualisme yang memisahkan antara laki-laki dengan perempuan pada orang Dayak Bahau.

Terdapat tiga jenis topeng Hudoq yang digunakan, yaitu: Hudoq nyam'ake, yang melambangkan pemuda yang gagah berani yang bertugas sebagai prajurit; Hudoq urung pakau, dikenakan oleh orang yang dituakan di kampung, yaitu pemimpin kelas menengah yang memberikan komando kepada prajurit saat perang; Hudoq ba'kap, yaitu dikenakan oleh pemimpin adat yang sekaligus mengepalai tarian Hudoq.

Ketiga jenis topeng Hudoq diatas memiliki kesamaan bentuk namun memiliki fungsi atau tugas yang berbeda-beda, seperti gambar berikut:

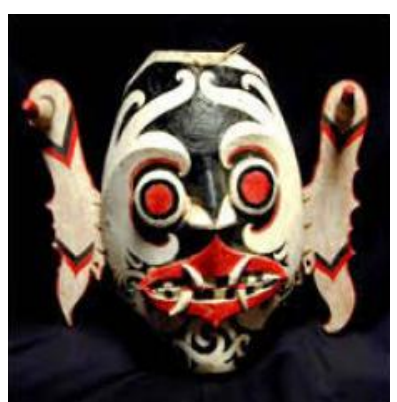

Topeng Hudoq Urung Pakau

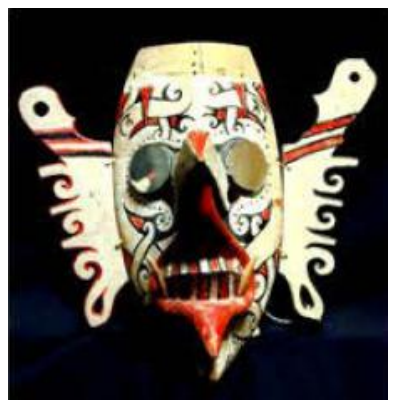

Topeng Hudoq Ba'kap

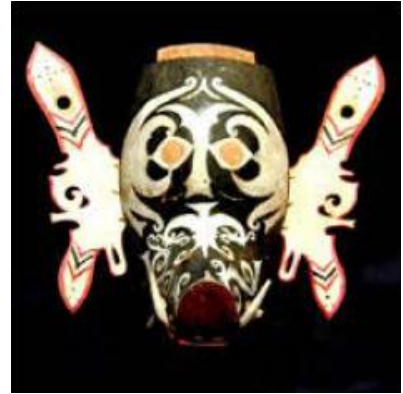

Topeng Hudoq Nyam'ake

Menurut kepercayaan orang Bahau, yang membawa padi dari kayangan adalah binatangbinatang, seperti rusa, babi, kera, burung-burung. Karena itulah topeng-topeng hudoq dibuat seperti binatang-binatang itu. Warna dari topeng tersebut didominasi oleh warna putih yang melambangkan pengabdian dan kesucian, hal ini mewakili dari tarian Hudoq yang sifatnya suci serta merupakan bentuk pengabdian dari masyarakat Dayak terhadap Dewanya. Warna yang kedua adalah merah, yang mewakili masyarakat Dayak yang berani dan pantang menyerah dalam mencapai keberhasilan panen mereka di ladang.

Berikut ini adalah analisis konsep dualisme dengan cara pembagian vertikal pada topeng Hudoq:
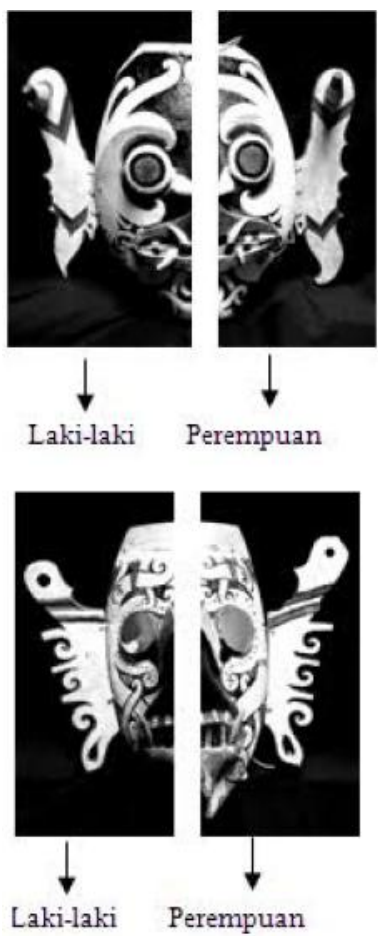


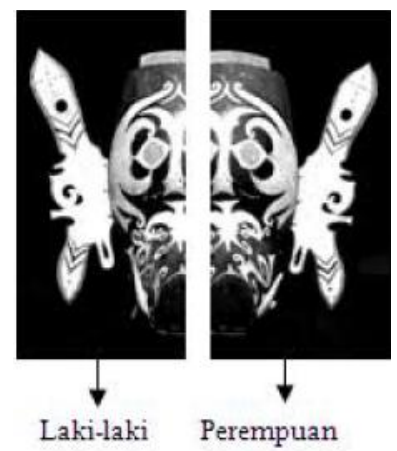

Analisis Unsur Dualisme

Lukisan atau hiasan yang terdapat pada topeng Hudoq di atas, apabila kita membuat garis di tengah topeng secara vertikal, mengakibatkan pembagian yang sama namun saling berlawanan. Hal ini melambangkan adanya dualisme yang mewakili laki-laki dan perempuan yang diterapkan pada suku tersebut.

Berikut ini adalah analisis konsep tripartit, dengan cara pembagian horizontal pada topeng Hudoq:
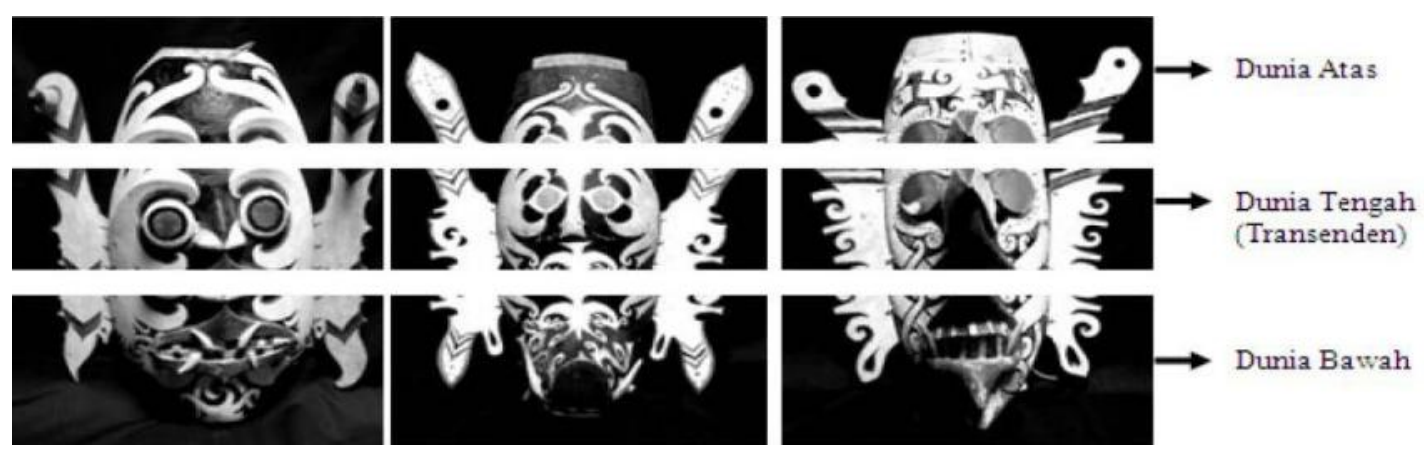

Gambar 7 Analisis Unsur Tripartit

Pada ketiga topeng Hudoq ini apabila dibagi tiga bagian secara horizontal, bentuk dan lukisan pada topeng ini melambangkan antara dunia atas, dunia tengah, dan dunia bawah. Dunia bawah dengan bentuk dan lukisan pada topeng yang mengarah ke bawah mendekati bumi, yang terdapat hasil panen serta hubungan sosial terhadap sesama, mewakili manusia. Dunia atas dengan bentuk dan lukisan pada topeng yang mengarah ke atas, dan dengan bentuk yang menjunjung tinggi dan agung, mewakili Sang Pencipta atau Dewa-nya. Dunia tengah dengan bentuk dan lukisan pada topeng yang mengarah ke samping mewakili suatu hal transenden dan berjiwa mistik yang berfungsi sebagai zona penghubung antara kedua dunia. Hal mistik ini diwujudkan melalui tari-tarian yang merupakan media perwujudan rasa syukur terhadap hasil panen yang diberikan oleh Dewa kepada masyarakat Dayak tersebut.

\section{KESIMPULAN}

F. Jiu Luwai (2002:5) menceritakan bahwa himpunan tulisan legenda tari ritual rakyat
Ga' ay Long Glaat ini bermula dari perkawinan Heleang Hebeung dari alam manusia di permukaan bumi dengan Selau Sen Yeang yang merupakan seorang Puteri dari kerajaan di dasar pusaran sungai. Dari pertemuan dan kawinnya Heleang Hebeung dengan Selau Sen Yeang telah membentuk hubungan makhluk gaib di dunia air dengan manusia. Yang ditandai dengan hubungan darah (oleh Heleang Hebeung) menjadi Hubungan Ritual Kepercayaan, karena adanya kepercayaan bahwa Selau Sen Yeang dan Buaq Selo dapat saling membantu, dalam bentuk pengaruh tidak nyata, dan pengaruh nyatakepada manusia keturunan Heleang Hebeung. Antara lain dalam bentuk pengobatan, pengusiran gangguan jahat serta pemulihan.

Sejak saat itu tari Hudoq menjadi sarana untuk menghadirkan kekuatan, pengaruh alam tradisi dan kepercayaan Dayak.Topeng dalam berbagai corak dan karakter yang menggambarkan kehadiran Tokoh yang berpengaruh dalam berbagai aspek kepercayaan tradisi Dayak. Sebagai contoh nyata aspek 
kehidupan yaitu pada musim perladangan dan biasanya musim menanam padiatau pada musim panen, digelar pelaksanaan upacara tari Hudoq dimana prinsipnya pelaksanaan upacara Hudoq adalah meminta kekuatan, perlindungan, dan keberhasilan pada usaha perladangan, usaha lainnya, kebersihan kampung dan kedamaian seluruh warga.

Tari Hudoq berfungsi sebagai tari upacara untuk menghadirkan kekuatan serta pengaruh alam yang merupakan tradisi dan kepercayaan Dayak Ga'ay pada musim panen. Topeng dalam berbagai corak dan karakter yang menggambarkan kehadiran tokoh dewa yang berasal dari sungai, gunung, maupun hutan belantara yang berpengaruh dalam berbagai aspek kepercayaan tradisi mereka. Pertunjukan tari Hudoq pada upacara panen padi penikmatnya adalah para penguasa dunia atas (Sang Pencipta dan roh-roh ghaib) serta dunia bawah (warga dasar sungai).

Terdapat tiga jenis topeng Hudoq yang digunakan, yaitu: Hudoq nyam'ake, yang melambangkan pemuda yang gagah berani yang bertugas sebagai prajurit; Hudoq urung pakau, dikenakan oleh orang yang dituakan di kampung, yaitu pemimpin kelas menengah yang memberikan komando kepada prajurit saat perang; Hudoq ba'kap, yaitu dikenakan oleh pemimpin adat yang sekaligus mengepalai tarian Hudoq.

\section{DAFTAR PUSTAKA}

Departemen Pendidikan dan Kebudayaan, 1994. Sejarah Kebudayaan Kalimantan. Jakarta: CV. Dwi Jaya Karya.

Dillistone, F. W. 2002. The Power of Symbols. Yogyakarta: Kanisius.

Haryanto, Sindung, 2010. Dunia Simbol Orang Jawa. Yogyakarta: Kepel Press
Herjayanti, Risna 2014, "Makna Simbolik Tari Hudoq Pada Upacara Panen Bagi Masyarakat Suku Dayak Ga'ay Kabupaten Berau Kalimantan Timur". Dalam tugas akhir mahasiswa program studi strata 1 Pendidikan Seni Tari Fakultas Bahasa dan Seni Universitas Negeri Yogyakarta.

Koentjaraningrat, 2009. Pengantar Ilmu Antropologi. Jakarta : PT. Rineka Cipta

Latif, Fauzia (2013), "Tarian dan Topeng Hudoq Kalimantan Timur". Dalam Jurnal Suatu Kajian Filsafat Seni.[online]. 4. 11 halaman. Tersedia: file://C:/Users/Acer/ Downloads/Documents/3481-9087-1-SM. pdf. [29 November 2018].

Odop, Nistain \& Frans Lakon. Dayak Menggugat: PINTU CERDAS

Soedarsono.1978. Pengantar Pengetahuan dan Komposisi Tari. Yogyakarta: ASTI.

Suardana, I Wayan. 2008. "Struktur Rupa Topeng Bali Klasik". Dimuat Dalam Jurnal IMAJI. [Online]. 4,(1). 80-94 halaman. Tersedia: https://journal.uny.ac.id/index. php/imaji/article/view/6703 . [05 Januari 2019]

Sutiyono. 1994. "Seni Tradisional dalam Arus Globalisasi Ekonomi". Jurnal Cakrawala Pendidikan. 3.

\section{Dari Internet:}

Kaskus, Hudoq Antara Sisi Mistis dan Eksotisme Tradisi Suku Dayak, https:// w w w . k a s k u s . co.id/t h read/ 582c31a21a997529598b4567/hudoqantara-sisi-mistis-dan-eksotisme-tradisisuku-dayak/diunduh pada tanggal 3 Desember 2018

Wikipedia. Suku Dayak, https://id.wikipedia. org/wiki/Suku_Dayak diunduh pada tanggal 3 Desember 2018

Wacana, Hudoq Topeng-Topeng Pelindung Orang Dayak, http://www.wacana. co/2017/04/topeng-hudoq-dayak/diunduh pada tanggal 3 Desember 2018. 